\title{
Male Reproductive System Disorder
}

National Cancer Institute

\section{Source}

National Cancer Institute. Male Reproductive System Disorder. NCI Thesaurus. Code C27019.

A non-neoplastic or neoplastic disorder that affects the male genital system.

Representative examples of non-neoplastic disorders include infection, testicular torsion, and undescended testis. Representative examples of neoplastic disorders include germ cell tumors, carcinoma, lymphoma, and sarcoma. 